\title{
Mercury concentrations in size-fractionated airborne particles at urban and suburban sites in Beijing, China
}

\author{
Zhangwei Wang, Xiaoshan Zhang*, Zuoshuai Chen, Yi Zhang \\ Research Center for Eco-Environmental Sciences, Chinese Academy of Sciences, Beijing 100085, PR China
}

Received 30 April 2005; received in revised form 19 November 2005; accepted 2 December 2005

\begin{abstract}
Mercury concentrations in size fractions of airborne particulate matter obtained from urban and suburban sites in Beijing in 2003 and 2004 are presented in this paper. The average concentrations of total particulate mercury were $1.18 \pm 0.82 \mathrm{ng} \mathrm{m}^{-3}$ with a range of $0.18-3.51 \mathrm{ng} \mathrm{m}^{-3}$ at the urban site and $0.68 \pm 0.62 \mathrm{ng} \mathrm{m}^{-3}$ with a range of $0.13-2.40 \mathrm{ng} \mathrm{m}^{-3}$ at the suburban site. This is much higher than what is found in Europe and Northern America. The results implie that significant anthropogenic sources in Beijing contribute to the concentration of particulate mercury in air and therefore, to the mercury deposition in this region. There are clear seasonal variations in concentration of particulate mercury with highest concentrations in winter at urban and suburban sites. This illustrates the important contribution from coal burning to particulate mercury during the heating season. The mercury concentration in each size fraction of airborne particulates was closely related to its size range. The highest mercury concentration was found in the size fraction less than $1.1 \mu \mathrm{m}$ with average concentrations of $0.59 \pm 0.50$ and $0.29 \pm 0.26 \mathrm{ng} \mathrm{m}^{-3}$ at the urban and suburban sites, respectively. The mercury in this size fraction accounts for $45.7 \pm 9.5 \%$ and $41.9 \pm 8.2 \%$ of the total particulate mercury, respectively. This implies that a large fraction of the particulate mercury in this area can be transported long range before it becomes deposited. Based on the concentrations of size-fractionated particulate mercury in ambient air, the dry deposition fluxes of mercury were estimated to $407 \mu \mathrm{g} \mathrm{m}^{-2} \mathrm{a}^{-1}$ at the urban site and $270 \mu \mathrm{g} \mathrm{m}^{-2} \mathrm{a}^{-1}$ at the suburban site. More than $90 \%$ of the deposition flux came from particles larger than $1.1 \mu \mathrm{m}$ despite a substantial fraction of the $\mathrm{Hg}$ found in particles less than $1.1 \mu \mathrm{m}$.
\end{abstract}

(C) 2006 Elsevier Ltd. All rights reserved.

Keywords: Mercury; Airborne particulates; Beijing; China

\section{Introduction}

Mercury is a persistent, toxic and bioaccumulative heavy metal. It exists primarily in three forms in atmosphere: gaseous mercury including elemen$\operatorname{tal}\left(\mathrm{Hg}^{0}\right)$ and divalent $\left(\mathrm{Hg}^{2+}\right)$ mercury, particulate

\footnotetext{
*Corresponding author. Tel.: + 861062849369 ; fax: +861062923563 .

E-mail address: zhangxsh@mail.rcees.ac.cn (X. Zhang).
}

and organic mercury (methylmercury). These different forms of mercury have different characteristics in terms of transport, deposition and influence on ecosystems (Lindqvist and Rodhe, 1985; Slemr et al., 1985; Schroeder and Munthe, 1998; Lin and Pehkonen, 1999; Boening, 2000). Removal rate of mercury from atmosphere depends largely on its chemical form. Elemental mercury $\left(\mathrm{Hg}^{0}\right)$ has an atmospheric lifetime of about 1 year, thus can be transported globally. Particulate mercury is 
reported to have much shorter residence time in the atmosphere, typically ranging from several days to a few weeks (Lindqvist and Rodhe, 1985; Slemr et al., 1985), thus it is likely to be deposited at intermediate distances from the source. Deposition rate of particulate mercury depend on the particle diameter, especially for dry deposition of particulate mercury (Lestari et al., 2003; Peters and Eiden, 1992; Davidson et al., 1985). Although the importance of fractionation measurements of airborne mercury is well recognized, only a very limited number of investigations have been conducted in China. Total particulate mercury concentrations were measured in Changchun (Fang et al., 2001), northeastern China, and sizefractionated particulate mercury data have been presented for Shanghai (Xiu et al., 2005). A few data are reported on atmospheric mercury in Beijing and especially mercury concentrations of size-fractionated airborne particulates are lacking. Large amounts of coal burning and other sources of air pollution in China are causing not only serious acid deposition but also an increasing atmospheric mercury emission (Hylander, 2001). It was estimated that about $218 \mathrm{t}$ mercury was emitted into the atmosphere in China in 1995 (Wang et al., 2000). In Guiyang, a typical air polluted city in China, average total gaseous mercury concentration was $8.4 \mathrm{ng} \mathrm{m}^{-3}$ (Feng et al., 2004).
In the work presented here size-fractionated airborne particles were sampled in 2003-2004 at one urban and one suburban site in Beijing, China, with subsequent analysis of mercury content. Dry deposition fluxes were estimated based on the concentrations of size fractioned particulate mercury.

\section{Experimental}

\subsection{Sites and sampling}

Two sampling sites in Beijing $\left(39^{\circ} 26^{\prime} \mathrm{N}, 116^{\circ} 30^{\prime} \mathrm{E}\right.$, $44 \mathrm{~m}$ a.s.1.) were used in this study. One sampling site was at Research Center for Eco-Environmental Sciences, located between the 4th and 5th ring road in the outskirt of Beijing urban area (hereafter called urban site). The other site was located at the campus of Beijing Petrol University in the northwestern area of Beijing, about $40 \mathrm{~km}$ from downtown of Beijing (hereafter called suburban site). Sites locations are shown in Fig. 1. Both sampling spots were on the roof of four-story buildings (about $15 \mathrm{~m}$ above ground).

In this study, size-fractionated particulate matter was collected from a high-volume air sampler with an impactor (SIBATA HV-1000F plus DJF-I impactor). This sampling equipment separates particles into the following size ranges: $>7.0$, 7.0-3.3, 3.3-2.0, and 2.0-1.1 and $<1.1 \mu \mathrm{m}$. Glass fiber filter (Dylec, AH-611; TOYO GB100R) was
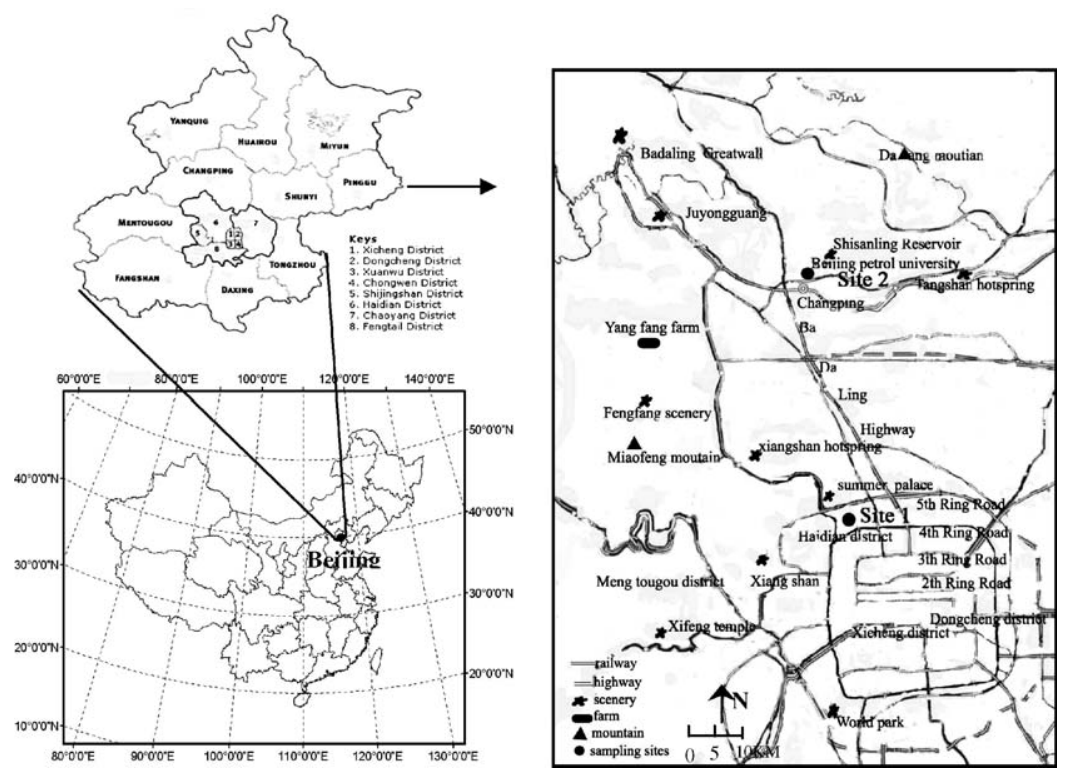

Fig. 1. Location of sampling sites (•) in Beijing. 
used to collect the particles. Prior to sampling the filters were baked at $500{ }^{\circ} \mathrm{C}$ for $5 \mathrm{~h}$ to remove any mercury present on the filter. Glass fiber filters have gained wide usage to collect atmospheric particulate mercury due to its good mechanical strength, low flow resistance, ability to withstand high temperature, cheap price and easy application (Petersen et al., 1995; Lu and Schroeder, 1999a).

Each sampling was conducted for $48 \mathrm{~h}$ with a constant air flow of $566 \mathrm{~L} \mathrm{~min}^{-1}$. Two samples were taken for all 12 months in 2003. In 2004, two monthly samples were collected only in January, April, July and October in 2004, representing winter, spring, summer and autumn, respectively. After sampling, the filters were packed and sealed in plastic bags and then immediately stored in freezer at about $-20{ }^{\circ} \mathrm{C}$. The amounts of mercury on the filters were measured within 1 month.

\subsection{Sample treatment and analysis}

The $\mathrm{Hg}$ on the filters was extracted by oxidizing the mercury to $\mathrm{Hg}^{2+}$ with a mixture of oxidants $\left(5 \% \mathrm{KMnO}_{4}\right.$ (potassium permanganate), $50 \%$ $\mathrm{H}_{2} \mathrm{SO}_{4}$ (sulfuric acid) and $5 \% \mathrm{~K}_{2} \mathrm{~S}_{2} \mathrm{O}_{8}$ (potassium persulfate)) using ultrasound bath for $30 \mathrm{~min}$ and subsequently laid aside for $12 \mathrm{~h}$ (Zhang et al., 1996). Hydroxylamine hydrochloride was used to reduce surplus oxidant. The concentrations of mercury in the extracts were measured by cold vapor atomic fluorescence spectrometry (CVAFS). The same procedure for extraction and analysis was used on blank filters. Calibration curves covering the appropriate concentration range were performed daily prior to analysis. The detection limit for particulate mercury in ambient air, calculated using three times the standard deviation, was about $3 \mathrm{pg} \mathrm{m}^{-3}$ for a $48 \mathrm{~h}$ sample at the flow rate employed. The precision (relative standard deviation) for sample replicate was better than $5 \%$. Extraction and analysis of samples was performed in a Class 100 clean room. All glassware used was cleaned according to the procedures discussed by Lu and Schroeder (1999b). The reagents for analysis were of ultra pure quality grade.

\section{Result and discussion}

\subsection{Validation of methods}

When a conventional filtration method employed in sampling the possible artifacts were usually concerned. In our work, a conventional highvolume five-stage impactor sampler (SIBATA HV1000 plus DJF-I Impactor) was used to get enough amount of particulates to be analyzed by CVAFS method. Using an impactor sampler could lead to less potential artifacts due to volatile particulates than filtration (Hughes et al., 2000) although the artifact would be still with the back up filter in final stage. The early experimental results of Fukuzaki and Ichikawa (1984) indicated that adsorption of gaseous mercury on the filters and vaporization of particulate mercury during the sampling with a high-volume air sampler had little effects on the accuracy of analytical values. Lynam and Keeler (2002) indicated that a significantly higher amount of particulate mercury would be collected onto a filter using the conventional methodology than that collected downstream of a KCl-coated annular denuder which removes gaseous reactive mercury. However, Lynam and Keeler (2005) also indicated that upstream $\mathrm{KCl}$-coated denuders could give an increase in particulate mercury concentration collected on the filter during periods of elevated concentration of atmospheric photochemical oxidants. Gold-coated denuders can be used upstream of particulates filtration for removing elemental $\mathrm{Hg}$. But it may sometime result in higher particulate $\mathrm{Hg}$ concentrations downstream than without the denuders due to mercury-bearing gold particles flaking off from the gold-coated denuders surface ( $\mathrm{Lu}$ and Schroeder, 1999a). Since the uncertainty existed in our sampling, a moderate loss or gain of particulate mercury concentrations and on the subsequently calculated dry deposition fluxes should be kept in mind.

CVAFS method used in our study is usually applied for sediments and biological samples. Very low-particulate mercury concentrations in the atmosphere make it difficult to use CVAFS method for analyzing the mercury accurately in airborne particulate samples. But a few authors (Fang et al., 2001; Xiu et al., 2005) have successfully used the method when the samples of large air volumes were collected using high-volume sampler in polluted area. In our work, $1630 \mathrm{~m}^{3}$ air was sampled using a high-volume air sampler capable of a flow rate of $566 \mathrm{~L} \mathrm{~min}^{-1}$. Based on this sampling volume, we calculated the detection limit of CVAFS method for particulate mercury to be about $3 \mathrm{pg} \mathrm{m}^{-3}$. This is much lower than the particulate mercury concentrations reported by Wang et al. (2002), Fang et al. (2001), Wang et al. (1996), Xiu et al. (2005). 


\subsection{Total particulate mercury}

The concentration of total particulate mercury was obtained by summarizing the five fractions (Fig. 2). The average total particulate $\mathrm{Hg}$ concentration at the urban site during the study period was $1.18 \pm 0.82 \mathrm{ng} \mathrm{m}^{-3}$ with a range of $0.18-3.51 \mathrm{ng} \mathrm{m}^{-3}$. At the suburban site, the average was $0.68 \pm$ $0.62 \mathrm{ng} \mathrm{m}^{-3}$, with a range of $0.13-2.40 \mathrm{ng} \mathrm{m}^{-3}$. This shows that the levels of particulate mercury in Beijing ambient air was comparable to that of cities such as Shanghai $\left(0.233-0.529 \mathrm{ng} \mathrm{m}^{-3}\right.$, Xiu et al., 2005), Changchun (0.022-1.984 $\mathrm{ng} \mathrm{m}^{-3}$, Fang et al., 2001), Chongqing (0.8-5.8 $\mathrm{ng} \mathrm{m}^{-3}$, Wang et al., 1996), Taiwan (0.34-5.8 $\mathrm{ng} \mathrm{m}^{-3}$, Tsai et al., 2003) and the Slovak Republic $\left(0.22-4.47 \mathrm{ng} \mathrm{m}^{-3}\right.$, Hladíková et al., 2001). The mercury levels are by far higher than that in most cities like Wisconsin $\left(0.0021-0.028 \mathrm{ng} \mathrm{m}^{-3}\right.$, Lamborg et al., 1995), Florida (0.0049-0.0093 $\mathrm{ng} \mathrm{m}^{-3}$, Guentzel et al., 2001), and Tokyo (0.03-0.15 $\mathrm{ng} \mathrm{m}^{-3}$, Sakata and Marumoto, 2002) as well as the rural areas of the Great Lakes region and Vermont (0.001-0.086 $\mathrm{ng} \mathrm{m}^{-3}$, Keeler et al., 1995). It appears that the large number of local anthropogenic sources of particulate mercury in Beijing contribute significantly to the concentration of $\mathrm{Hg}$ in Beijing air. The
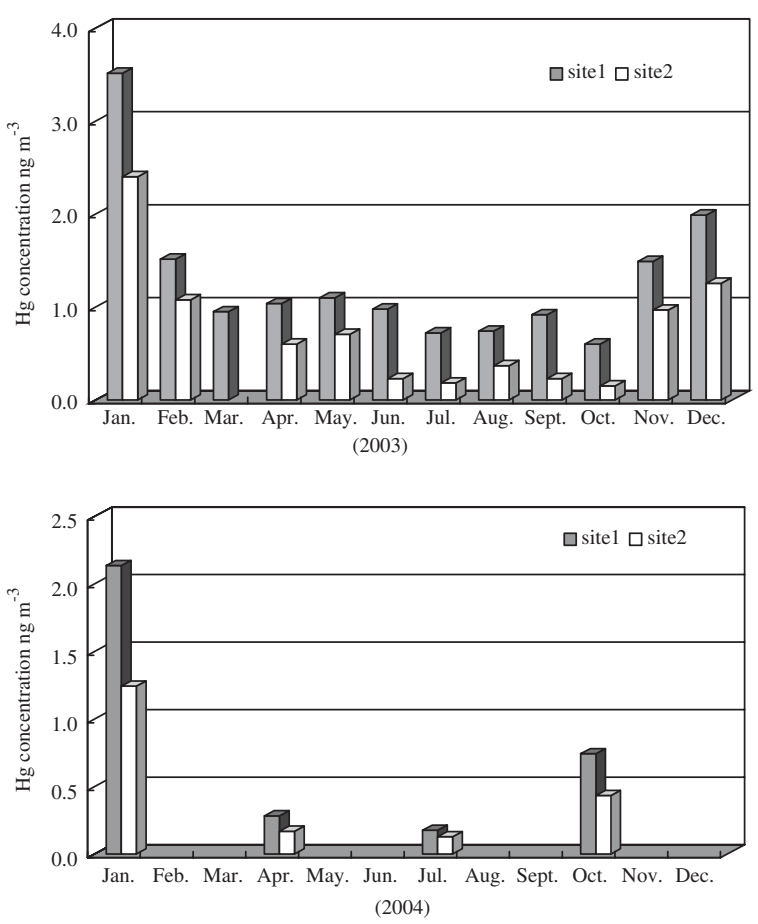

Fig. 2. Concentrations of total particulate mercury at two sampling sites. concentrations of particulate mercury were significantly higher at the urban site than the suburban site (Mann-Whitney test, $P=0.003$ ), reflecting the importance of anthropogenic mercury sources in the urban area. There is a clear seasonal variation of total particulate mercury with the highest concentration in winter at both the urban and the suburban site. This illustrates the important contribution of coal burning to particulate mercury in the heating season.

\subsection{Mercury in particle size fractions}

Fig. 3 shows the mean percentages of total particulate mercury in each size fraction during the sampling period. The highest $\mathrm{Hg}$ concentration was found in the fraction of particle size less than $1.1 \mu \mathrm{m}$, with the average concentration 0.59 and $0.29 \mathrm{ng} \mathrm{m}^{-3}$ at the urban and suburban sites, respectively. The mercury in this size fraction accounted for $45.7 \pm 9.5 \%$ and $41.9 \pm 8.2 \%$ total of the total particulate mercury. This implies that an significant amount of particulate mercury originating from the local anthropogenic sources in Beijing is transported long range.

$\square>7.0 u m$ ㄱ.0-3.3um $\square$ 3.3-2.0um $\square 2.0-1.1 \mathrm{um} \square<1.1 \mathrm{um}$

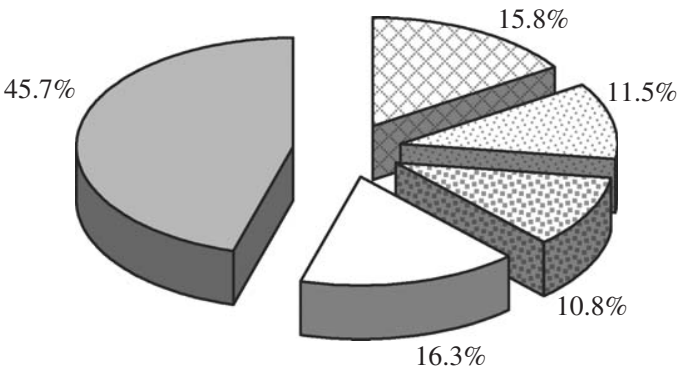

Site 1

$\square>7.0 \mathrm{um} \quad \square 7.0-3.3 \mathrm{um}$ [3.3-2.0um $\square$ 2.0-1.1um $\square<1.1 \mathrm{um}$

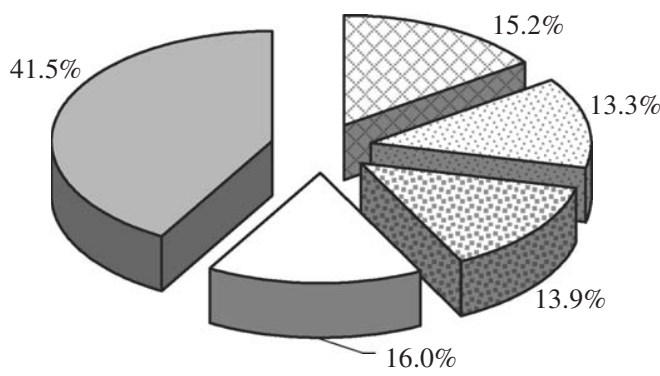

Site2

Fig. 3. Average size-based fractions of particulate mercury in urban and suburban sites. 
The monthly mean distribution of each size fraction to the total particulate mercury is illustrated in Fig. 4. The percentage of mercury in the particle size less than $1.1 \mu \mathrm{m}$ varied from $30 \%$ to $65 \%$ at the urban site and $25 \%$ to $65 \%$ at the suburban site. More than half of the particulate mercury existed in the two finest particle ranges, except in October 2003 at both sites, December 2003 at the suburban site, and April 2003 at the urban site only. These results agree well with those reported by Tsai et al. (2003) and Allen et al. (2001). It can be seen from Fig. 4 that there were almost no consistent seasonal trends in the relative contributions of the different size fractions. This implies that any artifacts influenced by temperature, such as volatilization, were quite small.

The seasonal concentrations and percentages of particulate mercury are also given in Table 1 .

\subsection{Dry deposition fluxes}

Dry deposition fluxes of atmospheric particulate mercury were calculated using size-fractionated deposition velocity and corresponding concentrations of ambient particulate mercury generated by this study. The total flux was then obtained by summing the fluxes of all the size fractions (Holsen
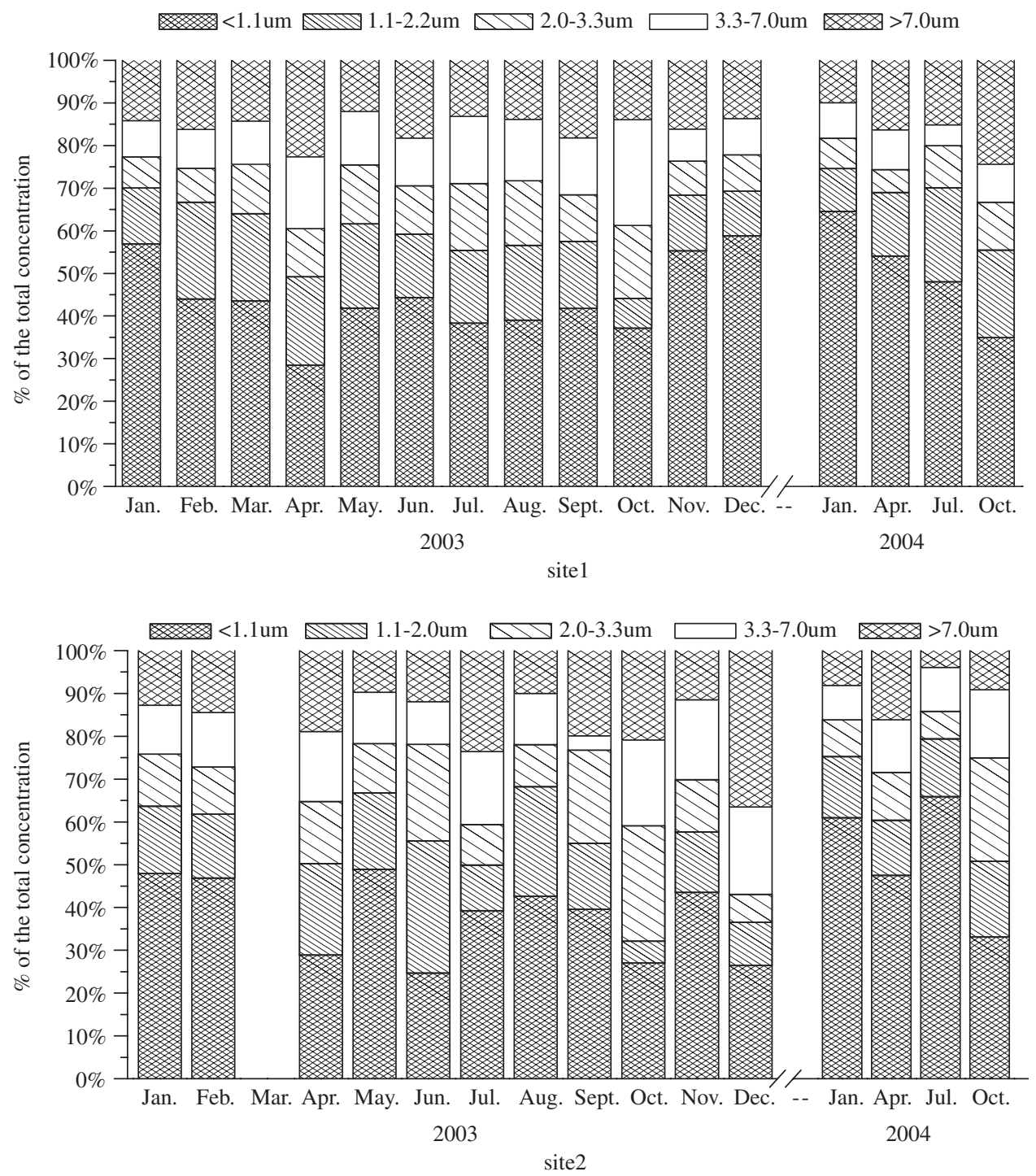

Fig. 4. Monthly means size-based fractions of particulate mercury in urban and suburban site. 
Table 1

Seasonal concentrations $( \pm$ SD) and size fractions of particulate mercury in urban and suburban sites in 2003(a) and 2004(b)

\begin{tabular}{|c|c|c|c|c|c|c|c|c|}
\hline \multirow[t]{2}{*}{ Size fraction $(\mu \mathrm{m})$} & \multicolumn{2}{|c|}{ Winter $\left(\mathrm{ng} \mathrm{m}^{-3}\right)$} & \multicolumn{2}{|c|}{ Spring $\left(\mathrm{ng} \mathrm{m}^{-3}\right)$} & \multicolumn{2}{|c|}{ Summer $\left(\mathrm{ng} \mathrm{m}^{-3}\right)$} & \multicolumn{2}{|c|}{ Autumn $\left(\mathrm{ng} \mathrm{m}^{-3}\right)$} \\
\hline & Urban & Suburban & Urban & Suburban & Urban & Suburban & Urban & Suburban \\
\hline \multicolumn{9}{|l|}{ (a) 2003} \\
\hline$<1.1$ & $1.23 \pm 0.61$ & $0.65 \pm 0.36$ & $0.46 \pm 0.18$ & $0.31 \pm 0.16$ & $0.33 \pm 0.12$ & $0.10 \pm 0.09$ & $0.30 \pm 13$ & $0.17 \pm 0.08$ \\
\hline$\%$ & 55.9 & 42.5 & 36.4 & 40.9 & 40.9 & 36.6 & 40.3 & 41.8 \\
\hline $2.0-1.1$ & $0.30 \pm 0.12$ & $0.21 \pm 0.12$ & $0.26 \pm 0.08$ & $0.14 \pm 0.03$ & $0.13 \pm 0.04$ & $0.06 \pm 0.06$ & $0.09 \pm 0.04$ & $0.05 \pm 0.03$ \\
\hline$\%$ & 13.5 & 14 & 20.2 & 19.3 & 16.3 & 23.7 & 12.8 & 12.4 \\
\hline $3.3-2.0$ & $0.17 \pm 0.06$ & $0.16 \pm 0.10$ & $0.16 \pm 0.07$ & $0.10 \pm 0.01$ & $0.11 \pm 0.02$ & $0.04 \pm 0.02$ & $0.11 \pm 0.07$ & $0.06 \pm 0.02$ \\
\hline$\%$ & 7.9 & 10.4 & 12.8 & 12.8 & 13.8 & 13.5 & 14.5 & 15.3 \\
\hline $7.0-3.3$ & $0.18 \pm 0.08$ & $0.24 \pm 0.08$ & $0.18 \pm 0.05$ & $0.10 \pm 0.01$ & $0.11 \pm 0.02$ & $0.03 \pm 0.009$ & $0.13 \pm 0.09$ & $0.04 \pm 0.03$ \\
\hline$\%$ & 8.3 & 15.6 & 14.3 & 13.7 & 13.5 & 12.5 & 17.2 & 9.8 \\
\hline$>7.0$ & $0.32 \pm 0.13$ & $0.27 \pm 0.21$ & $0.21 \pm 0.04$ & $0.10 \pm 0.02$ & $0.13 \pm 0.06$ & $0.04 \pm 0.02$ & $0.11 \pm 0.10$ & $0.08 \pm 0.02$ \\
\hline$\%$ & 14.5 & 17.6 & 16.3 & 13.4 & 15.4 & 13.7 & 15.3 & 20.8 \\
\hline TSP & $2.21 \pm 1.10$ & $1.52 \pm 0.87$ & $1.27 \pm 0.34$ & $0.75 \pm 0.20$ & $0.81 \pm 0.24$ & $0.26 \pm 0.18$ & $0.74 \pm 0.25$ & $0.40 \pm 0.15$ \\
\hline \multicolumn{9}{|l|}{ (b) 2004} \\
\hline$<1.1$ & $1.40 \pm 0.52$ & $0.76 \pm 0.21$ & $0.15 \pm 0.01$ & $0.08 \pm 0.004$ & $0.09 \pm 0.05$ & $0.08 \pm 0.08$ & $0.26 \pm 0.20$ & $0.14 \pm 0.01$ \\
\hline$\%$ & 64.5 & 61 & 54 & 47.5 & 48 & 65.9 & 34.9 & 33.1 \\
\hline $1.1-2.0$ & $0.22 \pm 0.01$ & $0.18 \pm 0.06$ & $0.04 \pm 0.01$ & $0.02 \pm 0.004$ & $0.04 \pm 0.03$ & $0.02 \pm 0.01$ & $0.15 \pm 0.11$ & $0.08 \pm 0.01$ \\
\hline$\%$ & 10.1 & 14.3 & 14.9 & 12.9 & 22.1 & 13.5 & 20.6 & 17.7 \\
\hline $2.0-3.3$ & $0.15 \pm 0.06$ & $0.11 \pm 0.02$ & $0.02 \pm 0.018$ & $0.020 \pm 0.006$ & $0.02 \pm 0.01$ & $0.01 \pm 0.004$ & $0.08 \pm 0.03$ & $0.11 \pm 0.03$ \\
\hline$\%$ & 7.1 & 8.6 & 5.4 & 11.1 & 9.9 & 6.4 & 11.2 & 24.2 \\
\hline $3.3-7.0$ & $0.18 \pm 0.01$ & $0.10 \pm 0.04$ & $0.03 \pm 0.01$ & $0.02 \pm 0.02$ & $0.01 \pm 0.005$ & $0.01 \pm 0.001$ & $0.07 \pm 0.01$ & $0.07 \pm 0.007$ \\
\hline$\%$ & 8.3 & 8.0 & 9.3 & 12.3 & 4.9 & 10.3 & 8.9 & 15.9 \\
\hline$>7.0$ & $0.21 \pm 0.05$ & $0.10 \pm 0.05$ & $0.05 \pm 0.01$ & $0.03 \pm 0.004$ & $0.02 \pm 0.02$ & $0.01 \pm 0.003$ & $0.18 \pm 0.11$ & $0.04 \pm 0.006$ \\
\hline$\%$ & 9.9 & 8.1 & 16.3 & 16.1 & 15.1 & 3.9 & 24.4 & 9.1 \\
\hline TSP & $2.13 \pm 0.42$ & $1.24 \pm 0.38$ & $0.28 \pm 0.02$ & $0.17 \pm 0.012$ & $0.18 \pm 0.12$ & $0.13 \pm 0.08$ & $0.74 \pm 0.30$ & $0.43 \pm 0.05$ \\
\hline
\end{tabular}

and Noll, 1992).

$F=\sum C_{\mathrm{i}} V_{\mathrm{d}}$

where $F$ is the total calculated flux, $C_{\mathrm{i}}$ and $V_{\mathrm{d}}$ are the particulate mercury concentration and the deposition velocity of each fraction. In this study, the deposition velocities $0.1,1.3$ and $2.9 \mathrm{~cm} \mathrm{~s}^{-1}$ (Nho-Kim et al., 2004) for continental land surface were chosen for the three size-fraction particles: submicron particles $(<1.1 \mu \mathrm{m})$, micron particles $(1.1-7.0 \mu \mathrm{m})$ and coarse particles $(>7.0 \mu \mathrm{m})$, respectively. The selected deposition velocities were calculated by the global multi-scale Chemistry and Transport Model MOCAGE over moderately rough surfaces under relatively mild friction velocity conditions (Nho-Kim et al., 2004). The calculated uncertainty of dry deposition fluxes relate directly to the above discussed sampling artifact. It was suggested by a reviewer of this paper to consider the influence of the artifacts on dry deposition fluxes in the order of $10 \%$.
The mercury dry deposition fluxes of total and size fractions of particles during different seasons at the urban and the suburban sites in 2003 are shown in Table 2.

The annual dry deposition fluxes of $\mathrm{Hg}$ were estimated to $407 \mu \mathrm{g} \mathrm{m}^{-2} \mathrm{a}^{-1}$ at the urban site and $270 \mu \mathrm{g} \mathrm{m}^{-2} \mathrm{a}^{-1}$ at the suburban site. These estimations are more than ten times greater than the values $\left(17.5 \mu \mathrm{g} \mathrm{m}^{-2} \mathrm{a}^{-1}\right)$ estimated for the areas in Centraland Northern Europe (Petersen et al., 1995). Dry deposition flux of mercury calculated was strongly related to the particle size. More than $90 \%$ of the deposition flux of particulate mercury came from particles larger than $1.1 \mu \mathrm{m}$ despite that a substantial fraction of the $\mathrm{Hg}$ was found in the particles less than $1.1 \mu \mathrm{m}$.

\section{Conclusions}

The averages of total particulate mercury concentrations were $1.18 \pm 0.82 \mathrm{ng} \mathrm{m}^{-3}$ at the urban site and $0.68 \pm 0.62 \mathrm{ng} \mathrm{m}^{-3}$ at the suburban site in 
Table 2

Dry deposition flux of particulate mercury in 2003

\begin{tabular}{|c|c|c|c|c|c|c|c|c|c|c|}
\hline \multirow[t]{2}{*}{ Size fraction } & \multicolumn{2}{|c|}{$\begin{array}{l}\text { Winter } \\
\left(\mu \mathrm{g} \mathrm{m}^{-2} \mathrm{month}^{-1}\right)\end{array}$} & \multicolumn{2}{|c|}{$\begin{array}{l}\text { Spring } \\
\left(\mu \mathrm{g} \mathrm{m}^{-2} \mathrm{month}^{-1}\right)\end{array}$} & \multicolumn{2}{|c|}{$\begin{array}{l}\text { Summer } \\
\left(\mu \mathrm{g} \mathrm{m}^{-2} \mathrm{month}^{-1}\right)\end{array}$} & \multicolumn{2}{|c|}{$\begin{array}{l}\text { Autumn } \\
\left(\mu \mathrm{g} \mathrm{m}^{-2} \mathrm{month}^{-1}\right)\end{array}$} & \multicolumn{2}{|c|}{$\begin{array}{l}\text { Year } \\
\left(\mu \mathrm{g} \mathrm{m}^{-2} \mathrm{a}^{-1}\right)\end{array}$} \\
\hline & Urban & Suburban & Urban & Suburban & Urban & Suburban & Urban & Suburban & Urban & Suburban \\
\hline$>7.0$ & 23.98 & 20.1 & 15.61 & 7.53 & 9.42 & 2.68 & 8.45 & 6.24 & 184.33 & 122.83 \\
\hline $7.0-1.1$ & 22.06 & 20.46 & 20.31 & 11.52 & 11.93 & 4.34 & 11.00 & 5.04 & 202.36 & 136.28 \\
\hline$<1.1$ & 3.2 & 1.68 & 1.2 & 0.79 & 0.86 & 0.25 & 0.77 & 0.43 & 20.3 & 10.5 \\
\hline total & 49.25 & 42.24 & 37.12 & 19.84 & 22.21 & 7.26 & 20.22 & 11.72 & 406.99 & 269.61 \\
\hline$\%(>7.0 /$ total $)$ & 48.7 & 47.6 & 42.1 & 37.9 & 42.4 & 36.9 & 41.8 & 53.3 & 45.3 & 45.6 \\
\hline$\%(7.0-1.1 /$ total $)$ & 44.8 & 48.5 & 54.7 & 58.1 & 53.7 & 59.8 & 54.4 & 43.1 & 49.7 & 50.5 \\
\hline$\%(<1.1 /$ total $)$ & 6.5 & 4.0 & 3.2 & 4.0 & 3.9 & 3.9 & 3.8 & 3.7 & 5.0 & 3.9 \\
\hline$\%$ (season/year) & 48.4 & 62.7 & 22.8 & 18.4 & 16.4 & 8.1 & 12.4 & 10.9 & - & - \\
\hline
\end{tabular}

Beijing, China. These concentrations are much higher than those reported for areas of Europe and Northern America. Dry deposition fluxes of particulate mercury were estimated to 407 and $270 \mu \mathrm{g} \mathrm{m}^{-2} \mathrm{a}^{-1}$ at the urban and suburban sites, respectively. The highest concentrations of particulate mercury were found in the urban area. The size distributions of particulate mercury were similar at the urban and the suburban sites. More than half of the particulate mercury was distributed in particle fractions less than $2.0 \mu \mathrm{m}$. The total concentration of airborne particulate mercury displayed distinctly seasonal variation, with the highest concentration in winter. These results indicate that the significant anthropogenic $\mathrm{Hg}$ sources in Beijing contribute to the particulate mercury and subsequently to the mercury depositions, especially during the coal burning in winter for heating. The results also suggested the importance of particulate mercury sources in this region to large-scale depositions of mercury, which largely related to the long range transport of fine particulates.

\section{Acknowledgments}

This work was funded by National Basic Research Program of China, no. 2003CB415003, Chinese Academy of Sciences (no. $\mathrm{KZCX}_{3}-\mathrm{SW}-443$ and no. $\left.\mathrm{KZCX}_{3}-\mathrm{SW}-424\right)$ and Natural Science Foundation of China (no. 40473055). The authors are grateful to Prof. Rolf David Vogt, University of Oslo and Dr. Thorjorn Larssen, Norwegian Institute for Water Research, for their valuable comments and suggestions. We are also thank our co-workers Zhou Jiabing, Mao Ting and Huang Yunbi for assistance with samples collecting.

\section{References}

Allen, A.G., Nemitz, E., Shi, J.P., et al., 2001. Size distributions of trace metals in atmospheric aerosols in the United Kingdom. Atmospheric Environment 35, 4581-4591.

Boening, W.D., 2000. Ecological effects, transport, and fate of mercury: a general review. Chemosphere 40, 1335-1351.

Davidson, C.I., Lindberg, S.F., Schmidt, J.A., et al., 1985. Dry deposition of sulfate onto surrogate surface. Journal of Geophysical Research 90, 2123-2130.

Fang, F., Wang, Q., Li, J., 2001. Atmospheric particulate mercury concentration and its dry deposition flux in Changchun City, China. Science of the Total Environment 281, 229-236.

Feng, X., Shang, L., Wang, S., et al., 2004. Temporal variation of total gaseous mercury in the air of Guiyang, China. Journal of Geophysical Research 109, D03303.

Fukuzaki, N., Ichikawa, Y., 1984. Determination of particulate mercury in air. Bunseki Kagaku (Analytical Chemistry) 33, 178-182 (in Japanese).

Guentzel, J.L., Landing, W.M., Gill, G.A., Pollman, C.D., 2001. Processes influencing rainfall deposition of mercury in Florida. Environmental Science and Technology 35 (5), 863-873.

Hladíková, V., Petrík, J., Jursa, S., Ursínyová, M., et al., 2001. Atmospheric mercury levels in the Slovak Republic. Chemosphere 45 (6-7), 801-806.

Holsen, T.M., Noll, K.E., 1992. Dry deposition of atmospheric particles: application of current models to ambient data. Environmental Science and Technology 26, 1807-1815.

Hughes, L.S., Allen, J.O., Bhave, P., et al., 2000. Evolution of atmospheric particles along trajectories crossing the Los Angeles basin. Environmental Science and Technology 34, 3058-3068.

Hylander, L.D., 2001. Global mercury pollution and its expected decrease after a mercury trade ban. Water, Air and Soil Pollution 125, 331-344.

Keeler, G., Glinsorn, G., Pirrone, N., 1995. Particulate mercury in the atmosphere: its significance, transport, transformation and sources. Water, Air and Soil Pollution 80 (1/4), 159-168.

Lamborg, C.H., Fitzgerald, W.F., Vandal, G.M., Rolfus, K.R., 1995. Atmospheric mercury in northern Wisconsin: sources and species. Water, Air and Soil Pollution 80, 189-198. 
Lestari, P., Oskouie, A.K., Noll, K.E., 2003. Size distribution and dry deposition of particulate mass, sulfate and nitrate in an urban area. Atmospheric Environment 37, 2507-2516.

Lin, C.J., Pehkonen, S.O., 1999. The chemistry of atmospheric mercury: a review. Atmospheric Environment 33, 2067-2079.

Lindqvist, O., Rodhe, H., 1985. Atmospheric mercury - a review. Tellus 37B, 136-159.

Lu, J.Y., Schroeder, W.H., 1999a. Comparison of conventional filtration and a denuder-based methodology for sampling of particulate-phase mercury in ambient air. Talanta 49, 15-24.

Lu, J.Y., Schroeder, W.H., 1999b. Sampling and determination of particulate mercury in ambient air: a review. Water, Air and Soil Pollution 112, 279-295.

Lynam, M.M., Keeler, G.J., 2002. Comparison of methods for particulate phase mercury analysis: sampling and analysis. Analytical and Bioanalytical Chemistry 374, 1009-1014.

Lynam, M.M., Keeler, G.J., 2005. Artifacts associated with measurement of particulate mercury in an urban environment: the influence of elevated ozone concentrations. Atmospheric Environment 39, 3081-3088.

Nho-Kim, E.-Y., Michoub, M., Peuchb, V.-H., 2004. Parameterization of size-dependent particle dry deposition velocities for global modeling. Atmospheric Environment 38, 1933-1942.

Peters, K.W., Eiden, R., 1992. Modeling the dry deposition velocity of aerosol particles to a spruce forest. Atmospheric Environment 21, 1561-1571.

Petersen, G., Iverfeldt, A., Munthe, J., 1995. Atmospheric mercury species over Central and Northern Europe model calculations and comparison with observations from Nordic
Air and Precipitation Network for 1987 and 1988. Atmospheric Environment 29, 47-67.

Sakata, M., Marumoto, K., 2002. Formation of atmospheric particulate mercury in the Tokyo metropolitan area. Atmospheric Environment 36, 239-246.

Schroeder, W.H., Munthe, J., 1998. Atmospheric mercury-an overview. Atmospheric Environment 32, 809-822.

Slemr, F., Schuster, G., Seiler, W., 1985. Distribution, speciation and budget of atmospheric mercury. Journal of Atmospheric Chemistry 3, 401-434.

Tsai, Y., Kuo, S., Lin, Y., 2003. Temporal characteristics of inhalable mercury and arsenic aerosols in the urban atmosphere in southern Taiwan. Atmospheric Environment 37, 3401-3411.

Wang, D., Li, X., Wu, C., 1996. Preliminary investigation on the atmospheric mercury in Chongqing. Chongqing Environment Science 18 (4), 58-61 (in Chinese).

Wang, Q., Shen, W., Ma, Z., 2000. Estimation of mercury emission from coal combustion in China. Environmental Science and Technology 34, 2711-2713.

Wang, W., Liu, J., Yang, S., Peng, A., 2002. Distribution of mercury on the aerosol in the atmospheric of Beijing. Journal of Shanghai Jiaotong University 36, 134-137 (in Chinese).

Xiu, G., Jin, Q., Zhang, D., et al., 2005. Characterization of sizefractioned particulate mercury in Shanghai ambient air. Atmospheric Environment 39, 419-427.

Zhang, X., Lu, L., Zhang, X., 1996. $\mathrm{KMnO}_{4}-\mathrm{H}_{2} \mathrm{SO}_{4}-\mathrm{K}_{2} \mathrm{~S}_{2} \mathrm{O}_{8}$ wet digestion for measurement the concentration of mercury in total suspend particles with cold atomic fluorescence spectrophotometer. Aridity Environment Inspection 10 (1), 10-12 (in Chinese). 